\title{
Rancang Bangun Alat Bantu Panjat Pohon Kelapa
}

\author{
Baso Nasrullah ${ }^{1 *}$, Syaharuddin Rasyid ${ }^{2}$, Muh. Rachmat Fajrin ${ }^{3}$ dan Arwandis ${ }^{4}$ \\ 1,2,3,4 Jurusan Teknik Mesin, Politeknik Negeri Ujung Pandang, Makassar 90245, Indonesia \\ *email: basonasrullah@poliupg.ac.id
}

\begin{abstract}
The design of coconut tree climbing aids purposes to make it easier and provide a sense of security to climb trees even though they do not have climbing skills. This tool uses a 2024 series hollow aluminum material which has a maximum tensile strength of $302 \mathrm{MPa}$ which is able to withstand a force of 7097Nmm which is greater than the maximum force that occurs which is 2000Nmm. This material has the ability to withstand a moment of $450.282 \mathrm{Nmm}$ greater than the moment that occurs of 100,000 Nmm, so the operator is safe without worry breaking. The testing of this tool has been proven to make it easier for humans who do not have climbing skills to a height of $6 \mathrm{~m}$ while those who have skills to climb coconut trees without tools can only reach a height of $3 \mathrm{~m}$. this is because climbers who have skills still feel awkward using coconut tree climbing aids. So it can be concluded that this climbing aid is safe and even people who do not have climbing skills can climb coconut trees safely.
\end{abstract}

Keywords: Climbing Aids; Coconut; Aluminum; Safety

\begin{abstract}
Abstrak: Rancang bangun alat bantu panjat pohon kelapa bertujuan untuk memudahkan dan memberi rasa aman untuk memanjat pohon meski tidak memiliki skill memanjat. Alat bantu ini menggunakan material aluminium hollow seri 2024 yang memiliki kekuatan tarik maksimum mencapai $302 \mathrm{MPa}$ yang mampu menahan Gaya sebesar $7097 \mathrm{Nmm}$ lebih besar dari gaya maksimum yang terjadi yaitu sebesar $2000 \mathrm{Nmm}$. Bahan ini memiliki kemampuan menahan momen sebesar $450.282 \mathrm{Nmm}$ lebih besar dari momen yang terjadi sebesar $100.000 \mathrm{Nmm}$, maka operator aman tanpa khawatir patah. pengujian alat bantu ini terbukti dapat memudahkan manusia yang tidak memiliki skill memanjat dengan ketinggian $6 \mathrm{~m}$ sedangkan yang memiliki skill memanjat pohon kelapa tanpa alat bantu hanya dapat mencapai ketinggian $3 \mathrm{~m}$. Hal ini disebabkan pemanjat yang memiliki skill masih merasa canggung menggunakan alat bantu panjat pohon kelapa. Jadi dapat disimpulkan alat bantu panjat ini sudah aman dan orang yang tidak mimiliki skill memanjatpun dapat memanjat pohon kelapa dengan aman.
\end{abstract}

Kata kunci : Alat Bantu Panjat; Pohon Kelapa; Aluminium; Keamanan

\section{PENDAHULUAN}

Beratnya resiko kerja bagi pemanjat pohon kelapa tidak tanggung-tanggung, resiko cedera berat hingga kematian yang harus dipikul setiap melakukan panjat pohon. Dalam kurun waktu setahun, sedikitnya 30 penyadap kelapa jatuh dari pohon kelapa saat bekerja. Memanjat pohon kelapa mempunyai resiko yang besar karena pohon kelapa yang dipanjat mencapai puluhan meter [1]. Data tahun 2014 lalu, menunjukan angka risiko kecelakaan kerja di sektor ini cukup tinggi. Bahkan, angka tersebut yang berhasil terdata, sedangkan yang belum kemungkinan jumlahnya lebih banyak. kecelakaan kerja para penderes nira ini umumnya terjadi di musim penghujan, sehingga perlunya perhatian lebih terkait angka kecelakaan tinggi dan pemberian santunan kecelakaan yang belum merata, serta penerapan teknologi keselamatan masih dalam uji coba [2].

Terdapat beberapa teknik memanjat pohon kelapa secara tradisional, yaitu:

1. Memanjat menggunkan kain yang dilingkarkan pada kedua kaki. Teknik ini bisa dikatakan masih berat bagi orang-orang tertentu karena membutuhkan kekuatan mencengkram yang besar dan kestabilan tubuh dalam bergerak.

2. Pohon kelapa diberi takikan secara selang-seling. Teknik seperti ini hampir sama dengan teknik pada no1. Akan tetapi teknik seperti ini rentan akan slip yang dialami pemanjat. 
3. Memanjat pohon menggunakan tangga, memakai tangga memanjat pohon juga masih beresiko. Karena tiupan angin dapat membuat hilangnya keseimbangan pada tangga yang akan berdampak pada pemanjat.

Dari berbagai teknik tersebut dibutuhkan skill untuk melakukannya, akan tetapi orang yang memiliki skill tersebut masih tebilang sedikit. Untuk itu dibutuhkan alat bantu agar yang tidak memiliki skill pun dapat memanjat pohon kelapa dengan aman. Seiring berkembangnya teknologi, khususnya dibidang pembuatan alat bantu panjat pohon kelapa telah banyak dibuat dengan berbagai keunikan desain yang berbeda-beda. Ada yang menggunakan motor sebagai penggerak hingga tenaga manual. dari sekian banyak pengembangan desain dari alat bantu panjat pohon ini belum ada yang menggunakan aluminium sebagai material dasar.

Berdasarkan permasalahan yang telah diuraikan, maka dapat dirumuskan adalah bagaimana mempermudah pemanjat yang tidak mempunyai keterampilan tanpa alat bantu?

\section{METODE PENELITIAN}

\section{A. Rancangan Alat}

Proses perancangan dilakukan untuk mengetahui desain awal alat panjat yang terdiri dari 2 (dua) bagian, yaitu upper tool dan lower tool, seperti diperlihatkan dalam Gambar 1. Seperti juga yang dilakukan untuk mendesain mini press tool [3], dan press tool untuk air V-bending [4][5].

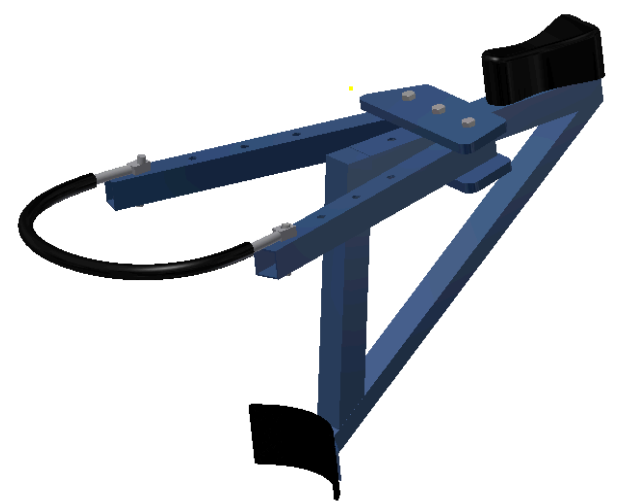

(a)

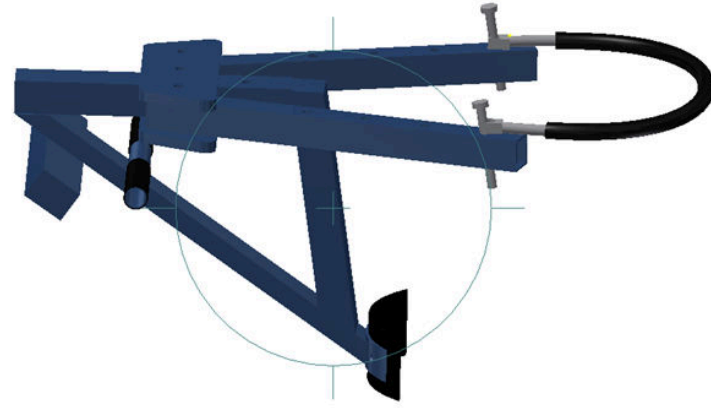

(b)

Gambar 1. (a) Assembly upper tool dan (b) lower tool

\section{B. Pembuatan dan Analisa Kekuatan Alat}

Proses pembuatan alat bantu panjat pohon kelapa harus sesuai dengan urutan-urutan atau prosedur dari perancangan yang telah dibuat. Objek penelitian kali ini menekankan pada perhitungan bagian kritis pada komponen alat bantu dan menghitung keamanan alat. Pengujian mekanik berupa pengujian tarik pada jenis material. Untuk mengetahui tegangan terbesar yang terjadi pada rancangan rangka akibat pembebanan.

\section{HASIL DAN PEMBAHASAN}

Pada bagian ini, hasil analisis kekuatan material dilakukan untuk mengetahui kemampuan dan performansi dari alat panjat pohon, begitu juga perhitungan rancangan serta hasil pengujian alat panjat pohon tersebut.

\section{A. Analisa Kekuatan Material}

Analisa kekuatan material yang dilakukan yakni melakukan pengujian kekuatan tarik dari material induk. Hasil dari pengujian ini akan dijadikan sebagai dasar perhitungan untuk mengetahui keamanan alat bantu panjat. 
162 Mukhtar, Peri Pitriadi. Simulasi Sistem Pengisian Bahan Bakar Otomatis untuk Generator Set pada Unit Excavator $313 D$

Tabel 1. Hasil analisis kekuatan mekanik material induk

\begin{tabular}{|c|c|c|c|c|}
\hline Sampel & $\begin{array}{c}\sigma u \\
(\mathrm{MPa})\end{array}$ & $\begin{array}{c}\varepsilon \\
(\%)\end{array}$ & $\begin{array}{c}\mathrm{r} \\
(\%)\end{array}$ & Jenis Patah \\
\hline 1 & 286,66 & 4.29 & 11.33 & patah ulet \\
\hline 2 & 306,66 & 2.86 & 8 & patah ulet \\
\hline 3 & 313,33 & 5.71 & 24 & patah ulet \\
\hline Rerata & 302.22 & 4.29 & 14.44 & \\
\hline
\end{tabular}

Data kekuatan material yang digunakan adalah:

- Hasil perhitungan dimensi hollow $\mathrm{A}=141 \mathrm{~mm}^{2}, \mathrm{~W}=8946 \mathrm{~mm}^{3}$

- Kekuatan tali sling max $211,2 \mathrm{~kg}$ beban

- Kekuatan maximum Baut $=889 \mathrm{Nmm}$

\section{B. Hasil Perhitungan Rancangan}

\section{- Analisis Gaya}

$$
\mathrm{F}=1000 \mathrm{~N}
$$

$$
\mathrm{F}_{\mathrm{c}}=1732 \mathrm{Nmm}
$$

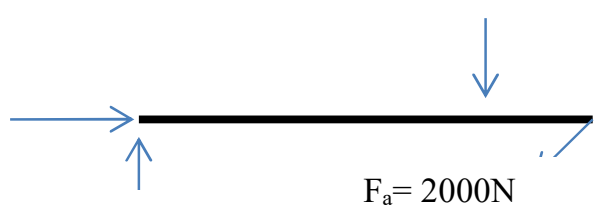

$$
\mathrm{F}_{\mathrm{b}}=1250 \mathrm{~N}
$$

Gambar 2. Hasil Analisis Gaya

\section{- Komponen Kritis}

- Perhitungan gaya ijin pada komponen kritis dapat dilakukan dengan menghitung tegangan $\operatorname{izin}\left(\sigma_{\mathrm{i}}\right)$, dimana: $\sigma_{\mathrm{u}}=302 \mathrm{Nmm}^{2}, \mathrm{~A}=141 \mathrm{~mm}^{2}$ dan SF (Safety Factor) $=6[6]$.

$\sigma_{\mathrm{i}}=\frac{302}{6}=50.3 \mathrm{Nmm}^{2}$

Sedangkan gaya izin dihitung [7]:

$$
\begin{aligned}
\mathrm{F}_{\mathrm{ijin}} & =\sigma_{\mathrm{i}} \times \mathrm{A} \\
& =50.3 \times 141=7097 \mathrm{Nmm}
\end{aligned}
$$

Besarnya gaya yang terjadi pada batang tumpuan sebesar 2000Nmm lebih kecil dari gaya izin pada hollow yaitu 7097Nmm maka komponen batang tumpuan aman.

- Perhitungan momen izin dengan data $F=1000 \mathrm{~N}, \mathrm{R}_{\mathrm{a}}=2000 \mathrm{~N}, \mathrm{R}_{\mathrm{b}}=1732 \mathrm{~N}$, serta gambar:

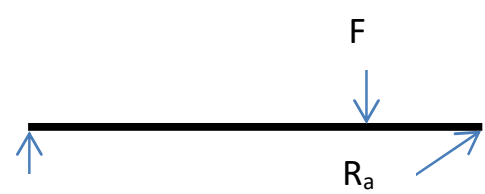

$\mathrm{R}_{\mathrm{b}}$

Gambar 3. Hasil Analisis Gaya

Momen tekuk dapat diperoleh sebagai berikut [8]: 


$$
\begin{aligned}
\mathrm{M}_{\mathrm{b}} & =\mathrm{R}_{\mathrm{a}} \cos 30(450)-\mathrm{F}(350) \\
& =(2000 \times 0,5 \times 450)-(1000 \times 350) \\
& =450000-350000 \\
& =100000 \mathrm{Nmm}
\end{aligned}
$$

Tegangan izin pada batang [9]:

$$
\sigma_{\mathrm{i}}=\frac{302}{6}=50.3
$$

Momen izin pada batang [10]:

$$
\begin{aligned}
\mathrm{M}_{\mathrm{izin}} & =\sigma_{\mathrm{i}} \mathrm{x} \mathrm{W}_{\mathrm{b}} \\
& =50.3 \times 8946 \\
& =450.282 \mathrm{Nmm}
\end{aligned}
$$

Besarnya momen yang terjadi pada batang tumpuan sebesar $100.000 \mathrm{Nmm}$ lebih kecil dari momen ijin pada hollow yaitu $450.282 \mathrm{Nmm}$, maka komponen batang tumpuan dapat dianggap aman.

\section{Hasil Pengujian Alat}

Pengujian alat dilakukan dengan menggunakan 3 orang sebagai operator, operator pertama adalah seorang mahasiswa yang tidak memiliki skill memanjat sedangkan operator kedua dan ketiga adalah seorang petani yang mampu memanjat pohon tanpa alat bantu.

Tabel 2. hasil Pengujian alat

\begin{tabular}{|l|l|c|c|}
\hline No & \multicolumn{1}{|c|}{ Eksperimen } & Ketinggian (meter) & Waktu (menit) \\
\hline 1 & Pertama (mahasiswa) & 6 & 4 \\
\hline 2 & Kedua (Petani) & 2 & 3 \\
\hline 3 & Ketiga (Petani) & 3 & 5 \\
\hline
\end{tabular}

Eksperimen pertama mampu mengoperasikan alat dengan baik, sedangkan eksperimen kedua dan ketiga masih merasa canggung menggunakan alat sehingga ketinggian dan waktu masih lebih kecil.

\section{KESIMPULAN}

Berdasarkan hasil dan pembahasan diatas, maka dapat disimpulkan beberapa hal, yaitu:

a. Desain rancangan sudah aman. Hal ini dibuktikan dengan beberapa kali uji alat, dan dari kekuatan material yang dipilih lebih besar dari tegangan yang terjadi pada alat pada pembebanan dibawah $100 \mathrm{~kg}$.

b. Alat bantu panjat pohon sudah memudahkan pemanjat yang tidak memiliki skill memanjat untuk memanjat pohon kelapa. Hal ini berdasarkan orang yang tidak memiliki skill memanjat lebih merasa nyaman memanjat dengan alat bantu dibandingkan yang terbiasa memanjat tanpa alat bantu masih merasa canggung. Dan juga ketinggian panjat yang tidak punya skill memanjat tanpa alat bantu lebih tinggi yaitu $6 \mathrm{~m}$ dibandingkan yang punya skill memanjat menggunakan alat bantu hanya mampu memanjat maksimum setinggi $3 \mathrm{~m}$.

\section{DAFTAR PUSTAKA}

[1] A. Mani and A. Jothilingam, "Design and fabrication of coconut harvesting robot: COCOBOT," Int. J. Innov. Res. Sci. Eng. Technol., vol. 3, no. 3, 2014.

[2] R. A. Imran, A. D. Purnamasari, and A. A. Sibarani, "Analisis Postur Kerja Posisi Memanjat pada Petani Gula Kelapa Kabupaten Banyumas," J. Media Tek. dan Sist. Ind., vol. 3, no. 2, pp. 49-58, 2020. 
164 Mukhtar, Peri Pitriadi. Simulasi Sistem Pengisian Bahan Bakar Otomatis untuk Generator Set pada Unit Excavator $313 D$

[3] R. Nur and M. A. Suyuti, "Mini Press Tool as Learning Practical: Designing, Manufacturing, and Analysis," J. Ind. Eng. Manag. Res., vol. 1, no. 2, pp. 9-14, 2020.

[4] M. A. Suyuti, R. Nur, and M. Iswar, "Rancang Bangun Press Tool Untuk Alat Bending Pelat Tipe Die-V Air Bending," Mach. J. Tek. Mesin, vol. 6, no. 1, pp. 39-45, 2020.

[5] R. Nur, M. A. Suyuti, and M. Iswar, "Designing and Manufacturing the Press Tool of Air Bending V Brake," Log. J. Ranc. Bangun dan Teknol., vol. 19, no. 3, pp. 38-43, 2019.

[6] R. Nur and M. A. Suyuti, Perancangan mesin-mesin industri. Deepublish, 2018.

[7] R. S. Khurmi and J. K. Gupta, A textbook of machine design. S. Chand publishing, 2005.

[8] V. D. Da Silva, Mechanics and strength of materials. Springer Science \& Business Media, 2005.

[9] K. Sularso and M. S. ME, “Dasar-Dasar Perencanaan dan Pemilihan Elemen Mesin,” Pradnya Paramita Jakarta, 1994.

[10] R. C. Juvinall and K. M. Marshek, Fundamentals of Machine Component Design. John Wiley \& Sons, 2020. 